\title{
Water Stress Effect on Cell Wall Components of Maize (Zea mays) Bran
}

\author{
Eleazar LUGO-CRUZ1, Francisco ZAVALA-GARCÍA ${ }^{1}$, Francisco Javier PICÓN-RUBIO², \\ Vania URÍAS-ORONA ${ }^{3}$, Humberto RODRÍGUEZ-FUENTES ${ }^{1}$, Juan Antonio VIDALES- \\ CONTRERAS ${ }^{1}$, Roberto CARRANZA-DE LA ROSA ${ }^{1}$, Guillermo NIÑO-MEDINA ${ }^{1 *}$
}

\author{
${ }^{I}$ Universidad Autónoma de Nuevo León, Facultad de Agronomiá, Francisco Villa S/N, C.P. 66050, Col. Ex-hacienda El Canadá, Escobedo, Nuevo León, México; \\ guillermo.ninomd@uanl.edu.mx;nino.medina.g@gmail.com (*correspondingauthor) \\ ${ }^{2}$ Universidad Autónoma de Nuevo León, Facultad de Medicina Veterinariay Zootecnia, Francisco Villa S/N, C.P. 66050, Col. Ex-hacienda El Canadá, Escobedo, \\ Nuevo León, México \\ ${ }^{3}$ Universidad Autónoma de Nuevo León, Facultad de Salud Públicay Nutrición, Av. Dr. Eduardo Aguirre Pequeñoy Yuriria, C.P. 64460, Col. Mitras Centro, \\ Monterrey, Nuevo León, México
}

\begin{abstract}
In México, around $82 \%$ of the total production of maize is grown under rainfed conditions leading to a water stress environment which affects physiologic and biochemical process of the plant. Maize bran is a composited plant material consisting mainly in aleurone layer, testa and pericarp; the cell walls of these tissues are composed of proteins, non-starch polysaccharides, phenolic acids and lignin which are potential bioactive substances for human nutrition. In this research it was investigated the effect of water stress on cell wall components in the bran of three genotypes of maize by applying irrigation and water stress treatments. The content of protein, lignin, arabinoxylans, total phenols and phenolic acids was performed in the bran of 'Cebú', 'DK2027' and 'DK2034' genotypes. Water stress applied through grain development stage increased protein levels of 'Cebú', 'DK2027' and 'DK2034' in 4.05, 16.13 and 0.40\% respectively. Respecting to lignin content, water stress increased levels at 1.28, 2.26 and 4.24\% for 'Cebú', 'DK2027' and 'DK2034', respectively. Arabinoxylans content also increased in water stress treatment at levels of 1.28, 2.26 and 3.66\% in 'Cebú', 'DK2027' and 'DK2034'. On the other hand, water stress treatment decreased the levels of total phenols and hydroxycinnamic acids in the three maize hybrids analysed. Reduction of total phenols was 35.34, 5.59 and 31.57\% for 'Cebú', 'DK2027' and 'DK2034', respectively. In addition, the levels of $t$-fierulic, $c$-ferulic and $p$-coumaric acids decreased 17.74, 23.93, 29.83\% in 'Cebú', 8.92, 8.62, 24.03\% in 'DK2027' and 13.66, 11.03, 10.38\% in 'DK2034' respectively.
\end{abstract}

Keywords: arabinoxylans, hydroxycinnamic acids, lignin, protein, total phenols, water stress, Zea mays bran

\section{Introduction}

Maize crop is important in nutrition and economy of the Mexico population because it is considered the centre of origin, domestication and diversification of this cultivation with around 60 different varieties in this territory (Kato et al., 2009). According to the Mexican Agriculture and Fishery Information Service (SIAP) data, in 2012 around 82\% (6, $616,152 \mathrm{ha}$ ) of the total production area with maize was rainfed established. In these conditions, maize crop frequently go through periods of water deficit which affects anatomic, morphologic, physiologic and biochemical process on plants (Farooq et al., 2009). On the other hand during development of plants, water stress affects anatomic, morphologic, physiologic and biochemical processes increasing the levels of reactive oxygen species, which has direct and indirect effects on secondary metabolism and therefore on antioxidant compounds synthesis (Farooq et al., 2009; Sharma et al.,
2012). The objective of this study was to determine changes in levels protein, lignin, arabinoxylans, total phenols and hydroxycinnamic acids in the bran of three maize genotypes grown under water stress.

\section{Materials and Methods}

\section{Plant material and experimental conditions}

Seeds of the non-drought tolerant maize hybrids 'Cebú', 'DK2027' and 'DK2034' were donated by Monsanto Company and cultivated in the research field of Universidad Autónoma de Nuevo León, Agronomy Faculty with a geographic localization in $25^{\circ} 52^{\prime} 13.5^{\prime \prime} \mathrm{N}$ and $100^{\circ} 02^{\prime} 22.5^{\prime \prime} \mathrm{W}$. Maize was grown during 2013 spring-summer cycle, sowing was performed on February $25^{\text {th }}$ on clay soil and water constants correspondent to field capacity and permanent wilt point were 
82

27 and 12\% respectively. Experimental units involved 4 furrows of $5 \mathrm{~m}$ long and $0.8 \mathrm{~m}$ spaced from each other and it was established a $0.1 \mathrm{~m}$ distance between plants in simple line. In irrigation (IR) treatment, field capacity was kept above 60\% during the whole cycle, while in the water stress (WS) treatment irrigation was suspended permanently from R1 phase (visible stigma, reached on May $10^{\text {th }}$ ) through R6 phase (physiologic maturity, reached on June $30^{\text {th }}$ ), all samples were harvested on July $10^{\text {th }}$ when water content was around $14-15 \%$.

\section{Bran preparation}

Grains of each experimental unit was soaked in water for $2 \mathrm{~h}$ and ground in an electrical mill. Later, each sample was suspended in $5 \mathrm{~L}$ of water; the bran was removed manually and recovered with a sieve and after that, defatted with acetone for 4 h. Finally samples were dried overnight at $40^{\circ} \mathrm{C}$ and ground to a particle size minor to $0.5 \mathrm{~mm}$ (mesh 35$)$.

\section{Protein, lignin and arabinoxylans}

Protein content was determined by Kjeldahl method ( $\mathrm{N} \mathrm{x}$ 6.25) (AOAC, 1990) using a Labconco Micro-Kjeldahl digestion and distillation system (Kansas City, MO, USA). Acid detergent lignin concentration (Goering and Van Soest, 1970) was determined by ANKOM 200/220 fibre analyzer (Fairport, NY, USA), using Ankom F57 filter bags with a pore size of 30 $\mu \mathrm{m}$. For arabinoxylans content, maize bran was suspended sodium phosphate buffer $(0.1 \mathrm{M})$ and treated with $\alpha$-amylase, protease and amyloglucosidase according to Bunzel et al. (2004) for starch and protein degradation. Arabinoxylans extraction was carried out according to Carvajal-Millan et al. (2006) with modifications. Briefly, maize bran was treated with $\mathrm{NaOH} 0.5$ $\mathrm{M}$ for $4 \mathrm{~h}$ at room temperature, followed by precipitation with ethanol for $4 \mathrm{~h}$ at $4^{\circ} \mathrm{C}$, after that arabinoxylans were recovered by filtration and finally freeze dried.

\section{Totalphenols and hydroxycinnamic acids}

Extraction of phenolics was carried out by alkaline hydrolysis followed by diethyl ether extraction and finally dissolved in $80 \%$ methanol according to the procedure described by Kim et al. (2006). Total phenols were performed using Folin-Ciocalteu analysis according to Chun and $\operatorname{Kim}$ (2004). Levels of phenolics were calculated based on calibration curve with ferulic acid in concentrations from 0 to $200 \mathrm{mg} \mathrm{L}^{-1}$ and results were expressed as micrograms equivalent of ferulic acid per gram of sample $\left(\mu \mathrm{gEAF} \mathrm{g} \mathrm{g}^{-1}\right)$. Hydroxycinnamic acids were analysed according to Zhao et al. (2005) using a HPLC equipment Agilent Technologies 1260 Infinity with G1311C quaternary pump and G4212B diode array detector (detection at $325 \mathrm{~nm}$ ) and a $\mathrm{C}_{18}$ SupelcoNucleosil column $(5 \mu \mathrm{M}, 250 \times 3 \mathrm{~mm})$. Levels of hydroxycinnamic acids were calculated based on a calibration curve with standards of $t$-ferulic, $c$-ferulic, $p$-coumaric, caffeic and sinapic acids, in concentrations from 0 to $50 \mathrm{mg} \mathrm{L}^{-1}$ and results were expressed as micrograms of each phenolic acid per gram of sample $\left(\mu g g^{-1}\right)$.

\section{Statistical analysis}

A randomized complete block design in locations was used; irrigation and water stress conditions represented each location. Four repetitions of 'Cebú', 'DK2027' and 'DK2034'treatments were established. Data analysis was carried out with Minitab 14.0 (Minitab Inc., 2004) and for simple comparison, Tukey test with $\alpha=0.05$ was used.
Table 1. Effect of water stress on protein, lignin and arabinoxylans in the studied maize hybrids

\begin{tabular}{lcccc}
\hline \multirow{2}{*}{ Genotype } & \multirow{2}{*}{ Treatment } & \multicolumn{3}{c}{ Component (\%) } \\
\cline { 3 - 5 } & & Protein & Lignin & Arabinoxylans \\
\hline \multirow{2}{*}{ 'Cebú' } & IR & $14.06^{\mathrm{a}}$ & $0.102^{\mathrm{a}}$ & $23.40^{\mathrm{a}}$ \\
& WS & $14.63^{\mathrm{a}}$ & $0.107^{\mathrm{a}}$ & $23.70^{\mathrm{a}}$ \\
\hline \multirow{2}{*}{ 'DK2027' } & IR & $13.14^{\mathrm{b}}$ & $0.104^{\mathrm{a}}$ & $19.85^{\mathrm{a}}$ \\
& WS & $15.26^{\mathrm{a}}$ & $0.119^{\mathrm{a}}$ & $20.30^{\mathrm{a}}$ \\
& & & & \\
\hline \multirow{2}{*}{ 'DK2034' } & IR & $14.91^{\mathrm{a}}$ & $0.125^{\mathrm{a}}$ & $17.20^{\mathrm{a}}$ \\
& WS & $14.97^{\mathrm{a}}$ & $0.134^{\mathrm{a}}$ & $17.83^{\mathrm{a}}$ \\
\hline
\end{tabular}

Means within a column for each hybrid with different letter are significantly different at $\mathrm{P} \leq 0.05$.

Table 2. Effect of water stress on the total phenols and hydroxycinnamic acids in the studied maize hybrids

\begin{tabular}{|c|c|c|c|c|c|}
\hline \multirow[b]{2}{*}{ Genotype } & \multirow[b]{2}{*}{ Treatment } & \multirow{2}{*}{$\begin{array}{l}\text { Total Phenols } \\
\left(\mu \mathrm{gFAFg}^{-1}\right)\end{array}$} & \multicolumn{3}{|c|}{ Hydroxycinnamic Acids $\left(\mu g^{-1}\right)$} \\
\hline & & & $t$-Ferulic & $c$-Ferulic & $p$-Coumaric \\
\hline \multirow{2}{*}{ 'Cebú' } & IR & $18931 \pm 707^{a}$ & $6560 \pm 77^{a}$ & $1989 \pm 25^{a}$ & $828 \pm 17^{a}$ \\
\hline & WS & $11483 \pm 433^{b}$ & $5396 \pm 48^{b}$ & $1513 \pm 70^{b}$ & $581 \pm 16^{b}$ \\
\hline \multirow{2}{*}{ 'DK2027' } & IR & $16598 \pm 625^{a}$ & $6265 \pm 63^{a}$ & $1833 \pm 24^{a}$ & $824 \pm 15^{a}$ \\
\hline & WS & $15671 \pm 886^{a}$ & $5706 \pm 116$ & $1675 \pm 24^{b}$ & $626 \pm 20^{b}$ \\
\hline \multirow{2}{*}{ 'DK2034' } & $\mathrm{IR}$ & $16643 \pm 558^{a}$ & $5827 \pm 79^{a}$ & $1759 \pm 57^{\mathrm{a}}$ & $983 \pm 27^{\mathrm{a}}$ \\
\hline & WS & $11388 \pm 464^{\mathrm{b}}$ & $5031 \pm 61^{b}$ & $1565 \pm 72^{\mathrm{a}}$ & $881 \pm 15^{\mathrm{a}}$ \\
\hline
\end{tabular}

Means within a column for each hybrid with different letter are significantly different at $\mathrm{P} \leq 0.05$.

\section{Results and Discussion}

\section{Protein, lignin and arabinoxylans}

Water stress applied through grain development stage increased protein in levels of 'Cebú', 'DK2027' and 'DK2034' increased 4.05, 16.13 and $0.40 \%$, respectively. Respecting to lignin content, water stress increase their levels at of 1.28, 2.26 and 4.24\% for 'Cebú', 'DK2027' and 'DK2034' and arabinoxylans content also increase in water stress treatment at levels of 1.28, 2.26 and 3.66\% in 'Cebú', 'DK2027' and 'DK2034' (Table 1).

Results found in the present study for protein are different than those reported by Ali et al. (2010), who reported that protein content of whole maize grain decreased significantly due to water stress on 'Agaiti-2002' and 'EV-1098' genotypes in 13.89 and $19.25 \%$ respectively. In the same way, Aydinsakir et al. (2013) found that protein content in maize grain was influenced by water deficit, with a decreasing level around 61.53 and $38.46 \%$ in 'Ant-190' and 'Safak' varieties, respecting to a full irrigation treatment.

Our data in lignin content, are different to conclusions of other studies where proteomic and metabolonic analysis of lignin synthesis in maize were analysed; Vincent et al. (2005), analysed the lignin content of the 'F2' ans ' $\mathrm{I}_{0}$ ' maize lines by thioacidolysis and they found that the lignin content was lower in leaves of plant subject to water deficit than in those of wellwatered plants and that was consistent with the levels of caffeic acid/5-hydroxyferulic 3-O-methyltransferase which is a key enzyme involved in lignin synthesis; in addition, Alvarez et al. (2008) concluded that water stress reduces lignin biosynthesis of the maize root xylem vessels of the cultivar 'FR697' and they support this conclusion based in the analysis of metabolites which showed an increase of free monolignols in xylem sap. 
To best of our knowledge there are not data available on the effect of water stress on arabinoxylans content in maize, but there are some studies of the effect this abiotic stress on wheat arabinoxylans. The present results had the same behaviour of the 'Superb' spring wheat variety studied by Zhang $e t$ al. (2010) but they obtained higher levels of arabinoxylans than the current ones, ranging from 9.76 to $12.6 \%$ at different temperature regimes. In addition, Rakszegi et al. (2014) also observed increasing levels of arabinoxylans in Magma and Fatima- 2 wheat varieties with 27.05 and $28.65 \%$, respectively.

\section{Total phenols and hydroxycinnamic acids}

Water stress treatment decreased the levels of total phenols and hydroxycinnamic acids in the three maize hybrids analysed. Reduction of total phenols was 35.34, 5.59 and $31.57 \%$ for 'Cebú', 'DK2027' and 'DK2034', respectively. In addition, the levels of $t$-ferulic, $c$-ferulic and $p$-coumaric acids decreased $17.74,23.93,29.83 \%$ in 'Cebú', 8.92, 8.62, 24.03\% in 'DK2027' and 13.66, 11.03, $10.38 \%$ in 'DK2034' respectively. Predominant hydroxycinnamic acid from bran extracts was $t$-ferulic (from 67 to $72 \%$ ) followed by $c$-ferulic (from 20 to $21 \%$ ) and p-coumaric (from 7 to $11 \%$ ) for both irrigation and water stress treatments, while caffeic and sinapic acids were found in traces or not detected in samples (Table 2).

To the best of our knowledge, there are not data available about the effect of water stress on total phenols and hydroxycinnamic acids of maize bran, but there are few reports that have published data of these assays from another anatomical part of the maize plant and products obtained from maize grain. Hura et al. (2008) evaluated the content of total phenols and $t$-ferulic acid in leaves of maize genotypes after two weeks of drought treatment and they found a total phenols decrease around 57 and 45\% for 'Ankora' and 'Nova' genotypes, which is higher than the present findings. In addition they observed that decrease of $t$-ferulic acid was around 35 and $31 \%$ after drought treatment in the studied hybrids which is in the range of the present study. Ali and Ashraf (2011) studied the effect of drought treatment on the secondary metabolites of maize leaves and they found decreasing levels around 27 and $25 \%$ in total phenols for ${ }^{\circ} \mathrm{EV}$ 1098' and 'Agaiti-2002' maize cultivars, being these results lower than the current data. Alvarez et al. (2008) analysed xylem sap of 'FR697' maize cultivar after 12 days of drought treatment and they observed the same pattern of hydroxycinnamic acids composition of the present study, reporting that $t$-ferulic acid was the predominant with a decreasing of $46 \%$ of this compound after drought treatment and this result was higher than the current experiment, in addition p-coumaric acid increased $286 \%$ which is a different behaviour comparing with the current results. Vuletić et al. (2014), analysed the effect of osmotic stress in root cell walls of the maize inbred line 'VA35' and they found that content of total phenols diminished 30\%, which is in agree with this results, but they also found a different behaviour in the analysis of hydroxycinnamic acids since they observed an increase of 49 and $18 \%$ in $t$-ferulic acid and $p$-coumaric respectively.

\section{Conclusions}

This study indicated that water stress had a positive effect on the content of protein, lignin and arabinoxylans, increasing their levels and had a negative effect on the content of total phenols and hydroxycinnamic acids. Further studies are necessary to determine the factors responsible of this behaviour.

\section{Acknowledgements}

Authors would like to acknowledge the financial support for this research provided by Consejo Nacional de Ciencia y Tecnología (CONACYT) through Investigación Científica Básica SEP-CONACYT 169635 granted to Guillermo Niño-Medina. Eleazar Lugo-Cruz thank to CONACYT for the Scholarship Postgraduate Studies granted.

\section{References}

Ali Q, Ashraf M (2011). Induction of drought tolerance in maize (Zea mays L.) due to exogenous application of trehalose: Growth, photosynthesis, water relations and oxidative defence mechanism. Journal of Agronomy and Crop Science 197:258-271.

Ali Q, Ashraf M, Anwar F (2010). Seed composition and seed oil antioxidant activity of maize under water stress. Journal of the American Oil Chemists' Society 87:1179-1187.

Alvarez S, Marsh EL, Schroeder SG, Schachtman P (2008). Metabolomic and proteomic changes in the xylem sap of maize under drought. Plant, Cell and Environment 31:325-340.

Association of Official Analytical Chemists (AOAC) (1990). Official Methods of Analysis. 15th ed. Association of Official Analytical Chemists. Washington, DC, USA.

Aydinsakir K, Erdal S, Buyuktas D, Bastug R, Toker R (2013). The influence of regular deficit irrigation applications on water use, yield, and quality components of two corn (Zea mays L.) genotypes. Agricultural Water Management 128:65-71.

Bunzel M, Funk C, Steinhart H (2004). Semipreparative isolation of dehydrodiferulic and dehydrotriferulic acids as standard substances from maize bran.Journal of Separation Science 27:1080-1086.

Carvajal-Millan E, Rascón-Chu A, Márquez-Escalante JA, Micard V, Ponce de León N, Gardea A (2006). Maize bran gum: extraction, characterization and functional properties. Carbohydrate Polymers 69:280-285.

Chun OK, Kim DO (2004). Consideration on equivalent chemicals in total phenolic assay of chlorogenic acid-rich plums. Food Research International 37:337-342.

Farooq M, Wahid A, Kobayashi N, Fujita D, Basra SMA (2009). Plant drought stress: Effects, mechanisms and management. Agronomy for Sustainable Development 29:185-212.

Goering HK, Van Soest PJ (1970). Forage fiber analysis (apparatus, reagents, procedures, and some applications). Agric Handbook No. 379. USDA-ARS, Washinton DC.

Hura T, Hura K, Grzesiak S (2008). Contents of total phenolics and ferulic acid, and PAL activity during water potential changes in leaves of maize single-cross hybrids of different drought tolerance. Journal of Agronomy and Crop Science 194:104112.

Kato TA, Mapes C, Mera LM, Serratos JA, Bye RA (2009). Origen y diversificación del máz: una revisión analítica. [Origin and diversification of maize: an analytical revision] Universidad Nacional 
84

Autónoma México. Comisión Nacional para el Conocimiento y Uso dela Biodiversidad, México DF.

Kim KH, Tsao R, Yang R, Cui SW (2006). Phenolic acid profiles and antioxidant activities of wheat bran extracts and the effect of hydrolysis conditions. Food Chemistry 95:466-473.

Minitab 14 statistical software (2004). Computer software. State College, PA: Minitab Inc. www.minitab.com.

Rakszegi M, Lovegrove A, Balla K, Láng L, Bedő Z, Veisz O, Shewry PR (2014). Effect of heat and drought stress on the structure and composition of arabinoxylans and $\beta$-glucan in wheat grain. Carbohydrate Polymers 102:557-565.

Sharma P, Jha AB, Dubey RS, Pessarakli M (2012). Reactive oxygen species, oxidative damage, and antioxidative defense mechanism in plants under stressful conditions. Journal of Botany. doi:10.1155/2012/217037.

Servicio de Información Agroalimentaria y Pesquera [Food and Fisheries Statistics Service] (SIAP). Anuario Estadístico de la Producción Agrícola. http://www.siap.gob.mx/cierre-de-la-produccion-agricolapor-cultivo/ (accessed on May 2015).
Vincent D, Lapierre C, Pollet B, Cornic G, Negroni L, Zivy M (2005). Water deficits affect caffeate $O$-methyltransferase, lignification, and related enzymes in maize leaves. A proteomic investigation. Plant Physiology 137: 949-960.

Vuletić M, Hadži-Taškovičšukalović V, Marković K, Kravić N, Vučinić $\check{Z}$, Maksimović V (2014). Differential response of antioxidative systems of maize (Zea mays $\mathrm{L}$.) roots cell walls to osmotic and heavy metal stress. Plan Biology 16:88-96.

Zhang B, Liu W, Chang SX, Anyia AO (2010). Water-deficit and high temperature affected water use efficiency and arabinoxylans concentration in spring wheat. Journal of Cereal Science 52:263-269.

Zhao YX, Ding MY, Liu DL (2005). Phenolic acids analysis in Ligusticum chuanxiong using HPLC. Journal of Chromatographic Science 43:389-393. 